ISSN: 2302-8556

\title{
Pengaruh Independensi, Pengalaman Kerja, Komitmen Organisasi, dan Motivasi Auditor Pada Kualitas Audit
}

\author{
Ida Bagus Putu Angga Mardika ${ }^{1}$ \\ I Wayan Suartana ${ }^{2}$ \\ ${ }^{1,2}$ Fakultas Ekonomi dan Bisnis Universitas Udayana (Unud), Bali, Indonesia \\ e-mail: anggamardika95@gmail.com
}

\begin{abstract}
ABSTRAK
Tujuan dari penelitian ini adalah untuk mengetahui pengaruh independensi, pengalaman kerja, komitmen organisasi, dan motivasi auditor pada kualitas audit di Inspektorat Provinsi Bali. Populasi penelitian adalah seluruh pejabat fungsional auditor (JFA) dan pejabat fungsional pengawas penyelenggara urusan pemerintah daerah (P2UPD) pada Inspektorat Provinsi Bali dan penentuan sampel menggunakan metode sampel jenuh atau sensus. Penelitian ini menggunakan sampel sebanyak 41 responden. Pengumpulan data dilakukan dengan kuesioner yang diukur dengan skala likert. Hasil penelitian ini menunjukkan bahwa independensi, pengalaman kerja, komitmen organisasi, dan motivasi auditor berpengaruh positif terhadap kualitas audit pada Inspektorat Provinsi Bali.
\end{abstract}

Kata kunci: Independensi, pengalaman kerja, komitmen organisasi, motivasi auditor, kualitas audit

\begin{abstract}
The aims of the current study are to determine the effect of independence, work experience, organization commitment, and auditor's motivation towards audit quality of the auditor in Inspectorate of Bali Province. The population of this study were all functional position auditor and all officials of local government affairs in Inspectorate of Bali Province and the sampling method was using saturated or census sample method. The numbers of samples used were 41 respondents. The data were collected by questionnaire measured by likert scale. The result of the current study shows that independence, work experience, organization commitment, and auditor's motivation have a positive and significant impact towards audit quality in Inspectorate of Bali Province.

Keyword: Independence, work experience, organization commitment, auditor's motivation, audit quality.
\end{abstract}

\section{PENDAHULUAN}

Masyarakat menginginkan terwujudnya pemerintahan yang baik (good governance) dan pemerintahan yang bersih (clean governance) dalam penyelenggaraan organisasi sektor publik yang efisien, efektif, transparan, akuntabel, serta bersih dari praktik penyelewengan dana, memaksa pemerintah untuk meningkatkan peran dari pengawasan internal. Penyelenggaraan good 
governance tidak hanya diperuntukkan bagi pemerintah pusat, namun pemerintah daerah juga dituntut untuk melakukan tata kelola pemerintahan yang baik dan bersih sehingga hal tersebut dapat tercipta disetiap lini pemerintahan. Publikasi Indonesian Corruption Watch (ICW) menyebutkan bahwa peran aparat pengawasan di daerah yang tidak efektif merupakan salah satu penyebab semakin meratanya kasus korupsi dan buruknya tata kelola pemerintahan daerah. "Korupsi masih merata di daerah, otonomi jadi automoney, sistem pengawasannya tidak cukup optimal sehingga mendorong pejabat publik melakukan praktek korupsi” (www.kompas.com, 2014). Berdasarkan data hasil pemeriksaan reguler yang dilaksanakan oleh Inspektorat Provinsi Bali terdapat peningkatan jumlah temuan dari tahun 2013-2015. Pada tahun 2013 terdapat jumlah temuan sebesar 496 temuan, tahun 2014 terdapat jumlah temuan sebesar 986 temuan, dan tahun 2015 terdapat jumlah temuan sebesar 1023. Peningkatan jumlah temuan ini menandakan bahwa penyelenggaraan pemerintahan Provinsi Bali masih kurang optimal yang disebabkan oleh kurang efektifnya pengawasan yang dilaksanakan oleh Inspektorat Provinsi Bali selaku Aparat Pengawasan Intern Pemerintah (APIP).

Inspektorat Provinsi Bali sebagai sebuah institusi yang melaksanakan tugas pengawasan terhadap penyelenggaraan pemerintahan daerah dipimpin oleh seorang Inspektur yang berada dibawah dan bertanggung jawab kepada Gubernur dan secara administrasi mendapat pembinaan dari Sekretaris Daerah. Inspektorat provinsi mempunyai tugas yang sama dengan auditor internal. Audit internal adalah audit yang dilakukan oleh unit pemeriksa yang merupakan bagian dari 
organisasi yang diawasi (Mardiasmo, 2005). Inspektorat provinsi mempunyai tugas untuk menyelenggarakan kegiatan pengawasan umum pemerintah daerah dan tugas lain yang diberikan kepala daerah. Inspektorat daerah diharapkan dapat lebih memberikan sumbangan bagi perbaikan efisiensi dan efektivitas dalam rangka peningkatan kualitas audit. Hasil pemeriksaan audit berupa temuan audit Inspektorat Provinsi Bali menunjukkan kemampuan auditor dalam mendeteksi kesalahan yang terdapat dalam laporan keuangan yang menunjukkan semakin bagusnya kualitas audit.

Kualitas audit auditor pemerintah saat ini tengah menjadi sorotan masyarakat seiring dengan maraknya kasus korupsi yang terjadi. Penyimpangan anggaran dalam bentuk tindak pidana korupsi menjerat mantan Bupati Bangli yang merugikan pemerintah sebesar Rp 1,395 miliar dari total dana bantuan sosial Rp 17 miliar pada tahun 2010, serta kasus yang melanda mantan Bupati Buleleng dalam kasus upah pungut Pajak Bumi dan Bangunan Kehutanan Perkebunan dan Pertambangan (PBB-KPP) tahun 2012 senilai Rp 1,6 miliar. Selan itu pula kasus pada tahun 2014 yang melibatkan mantan Bupati Klungkung atas pengadaan lahan untuk pembangunan dermaga yang merugikan Negara sebesar Rp 7 miliar.

Pengawasan intern yang dilakukan oleh Aparat Pengawasan Intern Pemerintah (APIP) yang terdapat dalam Sistem Pengendalian Intern Pemerintah (SPIP) terdiri dari audit, review, evaluasi, pemantauan dan kegiatan pengawasan lainnya. Pengawasan berfungsi membantu agar sasaran yang ditetapkan organisasi dapat tercapai, di samping itu pengawasan berfungsi mendeteksi secara dini terjadinya penyimpangan pelaksanaan, penyalahgunaan wewenang, pemborosan dan 
kebocoran (Sukriah and Dkk, 2009). Audit ini harus dilakukan oleh orang yang berkompeten dan independen guna menghasilkan laporan hasil audit yang berkualitas dan sesuai dengan informasi yang tersedia pada laporan keuangan yang di audit (Yushita and Triatmoko, 2013). Inspektorat daerah mempunyai tugas menyelenggarakan kegiatan audit pemerintah daerah dan tugas lain yang diberikan kepala daerah, sehingga dalam tugasnya inspektorat sama dengan auditor internal. Audit internal adalah audit yang dilakukan oleh unit pemeriksa yang merupakan bagian dari organisasi yang diawasi (Mardiasmo, 2005). Fungsi audit akan berjalan dengan baik apabila kualitas audit yang dihasilkan sesuai dengan standar pemeriksaan dan kode etik yang relevan.

Apa pun tugas yang dilakukan oleh auditor, yang dibutuhkan adalah sebuah hasil kerja yang berkualitas. Kualitas audit adalah sebagai kemungkinan ditemukannya dan dilaporkannya pelanggaran sistem akuntansi klien oleh auditor (Sari and Ramantha, 2015). Kemungkinan auditor untuk menemukan pelanggaran tergantung pada kemampuan teknis auditor. Keuangan perusahaan tergantung dari kompetensi auditor sedangkan kemauan untuk melaporkan temuan salah saji tersebut tergantung pada independensinya.

Independensi merupakan standar umum nomor dua dari tiga standar auditing yang ditetapkan oleh Ikatan Akuntan Indonesia (IAI) yang menyatakan bahwa dalam semua hal yang berhubungan dengan penugasan, independensi dalam sikap mental harus dipertahankan oleh auditor. Artinya auditor seharusnya berada dalam posisi yang tidak memihak siapapun karena ia melaksanakan pekerjaanya untuk kepentingan umum. 
ISSN: 2302-8556

E-Jurnal Akuntansi Universitas Udayana

Vol.27.3.Juni (2019): 2211-2238

Audit menuntut keahlian dan profesionalismenya yang tinggi. Keahlian tersebut tidak hanya dipengaruhi oleh pendidikan formal tetapi banyak faktor lain yang mempengaruhi antara lain adalah pengalaman. Auditor harus senantiasa bertindak sebagai seorang ahli dalam bidang akuntansi dan auditing dalam menyampaikan suatu pernyataan pendapat saat pelaksanaan audit. Pencapaian keahlian tersebut dimulai dengan pendidikan formalnya, yang diperluas melalui pengalaman-pengalaman selanjutnya dalam praktik audit (Ikatan Akuntan Indonesia, 2011). (Badjuri, 2011) menyatakan bahwa agar kualitas hasil audit terjaga, maka diperlukan pengalaman kerja sebagai auditor sektor publik.

Profesionalisme sendiri harus ditunjang dengan komitmen seseorang terhadap organisasinya. Keyakinan dan dukungan yang kuat oleh anggota organisasi terhadap nilai dan sasaran yang ingin dicapai organisasi ialah komitmen organisasi (Zeyn, 2011). Komitmen organisasi merupakan keadaan dimana seorang karyawan berniat memelihara dan bertanggungjawab atas keanggotaannya serta pemihakan pada suatu organisasi dan tujuan-tujuannya. Auditor melakukan pekerjaannya dengan tidak hati-hati karena tidak dimilikinya komitmen terhadap organisasi yang berdampak pada komitmen terhadap kualitas pekerjaannya (Fatimah, 2012). Adanya suatu komitmen dapat menjadi suatu dorongan bagi seseorang untuk bekerja lebih baik.

(B.Uno, 2007) mendefinisikan bahwa motivasi merupakan suatu dorongan internal dan eksternal dalam diri seseorang yang diindikasikan dengan adanya hasrat dan minat dorongan dan kebutuhan, harapan dan cita-cita, serta penghargaan dan penghormatan. Dalam konteks organisasi, motivasi adalah 
pemaduan antara kebutuhan organisasi dengan kebutuhan personil (Basrowi, 2008). Hal ini akan mencegah terjadinya ketegangan/konflik sehingga akan membawa pada pencapaian tujuan orgaisasi secara efektif. Perbankan mapun individu sangat membutuhkan motivasi bagi individu sagatlah berpengaruh terhadap perusahaan. Motivasi yang diterima oleh setiap masing-masing orang, dapat mempengaruhi tujuan dari organisasi tersebut. Motivasi yang tinggi juga dapat membantu dalam pencapaian tujuan organisasi.

Beberapa tahun terakhir, permasalahan hukum terutama berkaitan dengan korupsi, kolusi, dan nepotisme (KKN) dengan segala praktiknya seperti penyalahgunaan wewenang, penyuapan, pemberian uang pelicin, pungutan liar, pemberian imbalan atas dasar kolusi dan nepotisme serta penggunaan uang negara untuk kepentingan pribadi telah menjadi perhatian masyarakat dan dianggap sebagai suatu hal yang lazim terjadi di negara ini. Tuntutan masyarakat akan penyelenggaraan pemerintahan yang bersih dan bebas $\mathrm{KKN}$ menghendaki adanya pelaksanaan fungsi pengawasan dan sistem pengendalian intern yang baik atas pelaksanaan pemerintahan dan pengelolaan keuangan negara untuk menjamin bahwa pelaksanaan kegiatan telah sesuai dengan kebijakan dan rencana yang telah ditetapkan serta untuk menjamin bahwa tujuan tercapai secara hemat, efisien, dan efektif. Kualitas audit dalam hal pengelolaan dan pengawasan keuangan daerah yang dilaksanakan oleh Inspektorat Provinsi Bali diharapkan dapat menghindari terjadinya permasalahan-permasalahan yang disebutkan diatas. Oleh karena itu independensi, pengalaman, komitmen organisasi, dan motivasi auditor diharapkan dapat meningkatkan kualitas audit pemerintah daerah. 
ISSN: 2302-8556

E-Jurnal Akuntansi Universitas Udayana

Vol.27.3.Juni (2019): 2211-2238

Berdasarkan uraian di atas, maka rumusan masalah yang diangkat adalah 1) Apakah independensi berpengaruh pada kualitas audit? 2) Apakah pengalaman kerja berpengaruh pada kualitas audit? 3) Apakah komitmen organisasi berpengaruh pada kualitas audit? 4) Apakah motivasi auditor berpengaruh pada kualitas audit?

Adapun tujuan penelitian ini adalah: 1) Untuk memberikan bukti empiris pengaruh independensi pada kualitas audit; 2) Untuk memberikan bukti empiris pengaruh pengalaman kerja pada kualitas audit; 3) Untuk memberikan bukti empiris pengaruh komitmen organisasi pada kualitas audit; 4) Untuk memberikan bukti empiris pengaruh motivasi auditor pada kualitas audit.

Manfaat dari penelitian ini ada dua yaitu manfaat teoritis dan manfaat praktis. Secara teoritis hasil penelitian ini nantinya dapat berfungsi untuk memberikan dukungan pada teori keagenan serta teori-teori empiris yang terkait dengan pengaruh independensi, pengalaman kerja, komitmen organisasi, dan motivasi auditor pada kualitas audit. Secara praktis hasil penelitian ini nantinya dapat digunakan sebagai gambaran, bahan pertimbangan dan masukan bagi pimpinan Inspektorat Daerah Provinsi Bali untuk meningkatkan kualitas audit dalam melakukan tugas pemeriksaan laporan keuangan lembaga/instansi terkait pengelolaan dan tanggung jawab keuangan Negara.

Berdasarkan teori keagenan yang dikemukakan oleh (Jensen and Meckling, 1976), organisasi perusahaan merupakan jaringan kontraktual antara prinsipal dan agen. Hubungan kontrak ini berupa pendelegasian wewenang oleh prinsipal (stake holders) kepada agen (manajemen), dimana agen bertugas untuk memaksimalkan 
kesejahteraan prinsipal. Namun, agen justru cenderung memaksimalkan kesejahteraannya sendiri dengan mengorbankan kepentingan pemegang saham. Hubungan ini juga menimbulkan pertanggungjawaban pihak manajemen kepada stake holders atas sumber aset dan aset yang mereka kelola. Kedua pihak ini memiliki kepentingan yang tentunya berbeda. Posisi, fungsi, situasi, tujuan, kepentingan dan latar belakang prinsipal dan agen yang berbeda akan menimbulkan pertentangan dengan saling tarik menarik kepentingan (conflict of interest) dan pengaruh antara satu sama lain. Konflik kepentingan muncul dalam suatu teori yang menyebutkan bahwa adanya hubungan antara pemegang saham (sebagai prinsipal) dan manajemen (sebagai agen).

Seorang auditor yang menegakan independensinya, tidak akan terpengaruh dan tidak dipengaruhi oleh berbagai kekuatan yang berasal dari luar diri auditor dalam mempertimbangkan fakta yang dijumpainya dalam pemeriksaan. Berdasarkan penelitian yang dilakukan (Septriani, 2012) dan (Bawono and Singgih, 2010), independensi berpengaruh signifikan positif terhadap kualitas audit. Begitu pula dengan penelitian yang dilakukan oleh (Badjuri, 2011) diperoleh hasil bahwa independensi berpengaruh positif terhadap kualitas audit. Dari uraian diatas dapat dirumuskan hipotesis sebagai berikut:

$\mathrm{H}_{1}$ : Independensi berpengaruh positif pada kualitas audit.

Auditor yang berpengalaman diasumsikan dapat memberikan kualitas audit yang lebih baik dibandingkan dengan auditor yang belum berpengalaman. Hal ini dikarenakan pengalaman akan membentuk keahlian seseorang baik secara teknis maupun secara psikis. Menurut (Christiawan, 2002) pengetahuan auditor 
dalam bidang akutansi dan auditing akan meningkat seiring semakin banyaknya pengalaman yang dimiliki seorang akuntan. Berdasarkan penelitian yang dilakukan oleh (Hanjani Andreani, 2014), (Panggih Hastama 2015), dan (Agusti and Pertiwi 2013) ditemukan bahwa pengalaman kerja berpengaruh positif terhadap kualitas audit. Jadi pengalaman merupakan hal yang sangat penting bagi sebuah profesi yang membutuhkan profesinalisme yang sangat tinggi seperti auditor, karena pengalaman akan mempengaruhi kualitas audit seorang auditor. Dari uraian diatas dapat dirumuskan hipotesis sebagai berikut:

$\mathrm{H}_{2}$ : Pengalaman kerja berpengaruh positif pada kualitas audit.

Dalam menjalankan tugas atau profesi sebagai seorang auditor tentunya akan mendapatkan konflik ketika harus melaporkan temuan-temuan yang mungkin tidak menguntungkan kinerja manajemen. Karena auditor secara profesional dilandasi oleh kode etik profesi dan standar pemeriksaan, maka auditor berada dalam sebuah dilema dimana memenuhi kebutuhan klien berarti melanggar standar pemeriksaan dan kode etik profesi. Pelanggaran standar pemeriksaan dan kode etik mempunyai implikasi terhadap kualitas audit yang dihasilkan oleh auditor. Oleh karena itu, auditor secara profesional harus dapat mempertahankan kode etik dan standar pemeriksaan yang telah ditetapkan. Penelitian yang dilakukan oleh (Putri, 2015) dan (Suryantini, 2012) menyatakan bahwa komitmen organisasi berpengaruh positif pada kualitas audit. Dari uraian di atas dapat dirumuskan hipotesis penelitian sebagai berikut:

$\mathrm{H}_{3}$ : Komitmen organisasi berpengaruh positif pada kualitas audit. 
Motivasi merupakan salah satu faktor yang cukup penting pada kualitas hasil dari pekerjaan yang dihasilkan seseorang dalam menjalankan pekerjaannya, terutama untuk seorang auditor yang sering kali menjadikan motivasinya sebagai dorongan untuk menghasilkan laporan audit yang berkualitas. Berdasarkan penelitian yang dilakukan oleh (Effendy, 2010), (Hanjani Andreani, 2014), dan (Idawati, 2015) bahwa motivasi berpengaruh positif terhadap kualitas audit. Dari uraian diatas dapat dirumuskan hipotesis sebagai berikut:

$\mathrm{H}_{4}$ : Motivasi auditor berpengaruh positif pada kualitas audit.

\section{METODE PENELITIAN}

Penelitian ini dilakukan dengan pendekatan kuantitatif dengan jenis asosiatif. Penelitian asosiatif adalah bentuk penelitian dengan tujuan untuk mengetahui hubungan antara dua variabel atau lebih. Lokasi penelitian yang dipilih adalah di Kantor Inspekorat Provinsi Bali yang terletak di Jalan D.I. Panjaitan No. 14 Denpasar. Pemilihan pada Kantor Inspekorat Provinsi Bali sebagai lokasi penelitian didasarkan pada pertimbangan bahwa masih diperlukannya upaya peningkatan kualitas audit pada Inspektorat Provinsi Bali.

Jenis data yang digunakan dalam penelitian ini adalah sebagai berikut. 1) Data kualitatif, seperti tugas dan fungsi Inspektorat Provinsi Bali serta struktur dan susunan Inspektorat Provinsi Bali. 2) Data kuantitatif adalah jumlah pejabat fungsional auditor (JFA) dan pejabat fungsional pengawas penyelenggara urusan pemerintah daerah (P2UPD) yang bekerja di Inspektorat Provinsi Bali dan skor masing-masing indikator variabel diperoleh dari pengisian kuesioner yang telah dibagikan kepada audior yang bekerja di Inspektorat Provinsi Bali. 
Data penelitian ini bersumber dari data primer dan data sekunder. 1) Data primer berupa jawaban kuesioner dari responden.; 2) Data sekunder berupa jumlah pejabat fungsional auditor (JFA) dan pejabat fungsional pengawas penyelenggara urusan pemerintah daerah (P2UPD) yang bekerja di Inspektorat Provinsi Bali.

Populasi yang diteliti adalah seluruh pejabat fungsional auditor (JFA) dan pejabat fungsional pengawas penyelenggara urusan pemerintah daerah (P2UPD) yang berada di Inspektorat Provinsi Bali pada tahun 2017 yaitu sebanyak 41 orang. Penelitian ini menggunakan seluruh populasi yang ada yaitu metode sampel jenuh atau sensus. Metode ini digunakan karena dipertimbangkan dari ketersediaan waktu dan jumlah yang memungkinkan untuk dilakukan penelitian secara keseluruhan.

Pengumpulan data dalam penelitian ini dilakukan adalah sebagai berikut. 1) Kuesioner yang diberikan secara langsung kepada responden yang berada di lokasi penelitian, dan diukur dengan skala likert 5. Nilai dari skala likert yaitu, skor 1 = sangat tidak setuju (STS), 2 = tidak setuju (TS), 3 = cukup setuju (CS), dan 4 = setuju (S), 5 = sangat setuju (SS); 2) Observasi non partisipan, dimana peneliti mengamati, mencatat, mengutip, dan mengumpulkan data yang berkaitan dengan penelitian. Teknik analisis data yang digunakan dalam penelitian ini adalah uji validitas, uji reliabilitas, uji normalitas, uji multikolinearitas, uji heteroskedasitas, analisis statistik deskriptif, analisis regresi linier berganda, koefisien determinasi $\left(\mathrm{R}^{2}\right)$, uji kelayakan model (uji f), dan uji hipotesis (uji t). 
Ida Bagus Putu Angga Mardika dan I Wayan Suartana. Pengaruh ...

\section{HASIL DAN PEMBAHASAN}

Kuesioner dalam penelitian ini disebarkan kepada 41 responden, dimana hanya 38 yang dijadikan sampel karena sebanyak 3 kuesioner tidak kembali. Terdapat 20 responden laki-laki, dan 18 responden perempuan. Jenis kelamin digunakan untuk mengetahui proporsi responden pria dan wanita. Berdasarkan umur, responden yang berusia dibawah 26 tahun sebanyak 7 orang, berusia antara 26 hingga 35 tahun sebanyak 9 orang, berusia antara 36 hingga 45 tahun sebanyak 13 orang, dan responden yang berusia diatas 45 tahun sebanyak 9 orang. Lamanya bekerja digunakan untuk mengetahui proporsi pengalaman responden dalam mengaudit. Responden yang berpengalaman mengaudit di kurang dari 1 tahun atau sama dengan 1 tahun sebanyak 2 orang, kurang dari 5 tahun atau sama dengan 5 tahun sebanyak 20 orang dan lebih dari 5 tahun sebanyak 16 orang. Tingkat pendidikan digunakan untuk mengetahui proporsi tingkat pendidikan terakhir yang dimiliki responden. Responden yang memiliki tingkat pendidikan S1 sebanyak 24 orang dan S2 sebanyak 14 orang. Jabatan digunakan untuk mengetahui kedudukan responden pada Inspektorat Provinsi Bali. Responden yang menjadi auditor muda sebanyak 1 orang, auditor madya sebanyak 4 orang, auditor pertama sebanyak 23 orang, P2UPD Muda sebanyak 7 orang, dan P2UPD madya sebanyak 3 orang.

Pengujian validitas dengan menghitung nilai pearson correlation. Suatu instrumen akan dikatakan valid apabila nilai $\mathrm{r}$ pearson correlation terhadap skor total di atas 0,30 (Sugiyono, 2014). Tabel 1 menyajikan hasil uji validitas instrumen penelitian sebagai berikut : 
ISSN: 2302-8556

E-Jurnal Akuntansi Universitas Udayana

Vol.27.3.Juni (2019): 2211-2238

Tabel 1.

Hasil Uji Validitas

\begin{tabular}{|c|c|c|c|}
\hline Variabel & Instrumen & Pearson Correlation & Keterangan \\
\hline \multirow{4}{*}{$\begin{array}{l}\text { Independensi } \\
\text { (X1) }\end{array}$} & $\mathrm{X} 1.1$ & 0,615 & Valid \\
\hline & $\mathrm{X} 1.2$ & 0,610 & Valid \\
\hline & $\mathrm{X} 1.3$ & 0,822 & Valid \\
\hline & X1.4 & 0,748 & Valid \\
\hline \multirow{5}{*}{$\begin{array}{l}\text { Pengalaman Kerja } \\
\text { (X2) }\end{array}$} & $\mathrm{X} 2.1$ & 0,464 & Valid \\
\hline & $\mathrm{X} 2.2$ & 0,633 & Valid \\
\hline & $\mathrm{X} 2.3$ & 0,678 & Valid \\
\hline & $\mathrm{X} 2.4$ & 0,749 & Valid \\
\hline & X3.1 & 0,316 & Valid \\
\hline \multirow{6}{*}{$\begin{array}{l}\text { Komitmen Organisasi } \\
\text { (X3) }\end{array}$} & X3.2 & 0,450 & Valid \\
\hline & $\mathrm{X} 3.3$ & 0,559 & Valid \\
\hline & X3.4 & 0,494 & Valid \\
\hline & $\mathrm{X} 3.5$ & 0,636 & Valid \\
\hline & X3.6 & 0,630 & Valid \\
\hline & $\mathrm{X} 4.1$ & 0,571 & Valid \\
\hline \multirow{4}{*}{$\begin{array}{l}\text { Motivasi Auditor } \\
\text { (X4) }\end{array}$} & $\mathrm{X} 4.2$ & 0,750 & Valid \\
\hline & $\mathrm{X} 4.3$ & 0,622 & Valid \\
\hline & $\mathrm{X} 4.4$ & 0,604 & Valid \\
\hline & Y.1 & 0,600 & Valid \\
\hline \multirow{4}{*}{$\begin{array}{l}\text { Kualitas Audit } \\
\text { (Y) }\end{array}$} & Y.2 & 0,591 & Valid \\
\hline & Y.3 & 0,728 & Valid \\
\hline & Y.4 & 0,726 & Valid \\
\hline & Y.5 & 0,577 & Valid \\
\hline
\end{tabular}

Sumber: Data diolah, 2018

Berdasarkan Tabel 1 dapat dilihat bahwa nilai Pearson Correlation dari masing-masing pernyataan adalah positif dan lebih dari 0,30. Hal ini menunjukkan bahwa pernyataan dalam kuesioner adalah valid.

Pengujian reliabilitas menunjukkan sejauh mana suatu alat pengukur dapat dipercaya atau diandalkan. Uji ini dilakukan terhadap instrumen dengan koefisien Cronbach's Alpha. Apabila nilai koefisiennya lebih besar dari 0,6 maka instrumen yang digunakan reliabel (Ghozali, 2013). Tabel 2 menyajikan hasil uji reliabilitas instrumen penelitian. 
Tabel 2.

Hasil Uji Reliabilitas

\begin{tabular}{ccc}
\hline Variabel & Cronbach's Alpha & Keterangan \\
\hline Independensi (X1) & 0,654 & Reliabel \\
Pengalaman Kerja (X2) & 0,628 & Reliabel \\
Komitmen Organisasi (X3) & 0,643 & Reliabel \\
Motivasi Auditor (X4) & 0,619 & Reliabel \\
Kualitas Audit (Y) & 0,633 & Reliabel \\
\hline
\end{tabular}

Sumber: Data diolah, 2018

Berdasarkan Tabel 2 terlihat bahwa keenam instrumen penelitian memiliki koefisien Cronbach's Alpha lebih besar dari 0,6 sehingga pernyataan dalam kuesioner tersebut reliabel.

Uji normalitas dilakukan untuk menguji apakah dalam sebuah model regresi (variabel dependen atau variabel independen ataupun keduanya) memiliki distribusi normal atau tidak. Pengujian normalitas data penelitian ini menggunakan metode Kolmogorov-Smirnov. Data penelitian dikatakan berdistribusi normal apabila nilai Asymp. Sig (2-tailed) lebih besar daripada level of significant yang dipakai yaitu 0,05 (Suyana, 2012). Hasil uji normalitas penelitian disajikan pada Tabel 3 sebagai berikut.

Tabel 3.

Hasil Uji Normalitas

\begin{tabular}{lc}
\hline \multicolumn{1}{c}{ Kolmogrov-Smirnov } & Unstandardized Residual \\
\hline $\mathrm{N}$ & 38 \\
Kolmogorov-Smirnov Z & 0,659 \\
Asymp. Sig. (2-tailed) & 0,777 \\
\hline
\end{tabular}
Sumber: Data diolah, 2018

Tabel 3 menunjukkan bahwa nilai signifikansi sebesar $0,777>0,05$. Hal ini berarti model regresi dalam penelitian ini berdistribusi normal.

Uji multikolinearitas bertujuan untuk menguji apakah model regresi ditemukan adanya korelasi antara variabel bebas. Multikolinearitas dapat dilihat dari nilai tolerance maupun dari nilai variance influence factor (VIF). Jika nilai 
ISSN: 2302-8556

E-Jurnal Akuntansi Universitas Udayana Vol.27.3.Juni (2019): 2211-2238

tolerance lebih besar dari $10 \%$ atau VIF kurang dari 10 maka dapat dikatakan model telah bebas dari masalah multikolinearitas. Hasil uji multikolonearitas penelitian disajikan pada Tabel 4 sebagai berikut.

Tabel 4.

Hasil Uji Multikolinearitas

\begin{tabular}{ccccc}
\hline Model & Variabel & Tolerance & VIF & Keterangan \\
\hline 1 & X1 & 0,811 & 1,233 & Bebas Multikolinearitas \\
& X2 & 0,745 & 1,343 & Bebas Multikolinearitas \\
& X3 & 0,797 & 1,255 & Bebas Multikolinearitas \\
& X4 & 0,988 & 1,012 & Bebas Multikolinearitas \\
\hline
\end{tabular}

Sumber: Data diolah, 2018

Berdasarkan Tabel 4 dapat dilihat bahwa nilai tolerance pada masingmasing variabel lebih besar dari $10 \%$, demikian pula dengan VIF masingmasing variabel lebih kecil dari 10. Hal ini berarti model regresi bebas dari masalah multikolinearitas.

Uji heteroskedastisitas dilakukan untuk mengetahui apakah di dalam model regresi terjadi ketidaksamaan varians pada residual dari satu pengamatan ke pengamatan lainnya. Uji heteroskedastisitas dapat dianalisis melalui metode Glejser dengan meregresikan nilai absolute residual sebagai variabel terikat dengan variabel bebas. Suatu model regresi akan dikatakan bebas dari heteroskedastisitas apabila signifikansi t tiap variabel bebas diatas 0,05. Hasil uji heteroskedastisitas penelitian disajikan pada Tabel 5 sebagai berikut.

Tabel 5.

Hasil Uji Heteroskedastisitas

\begin{tabular}{ccc}
\hline Model & Sig. & Keterangan \\
\hline X1 & 0,878 & Bebas Heteroskedastisitas \\
X2 & 0,192 & Bebas Heteroskedastisitas \\
X3 & 0,135 & Bebas Heteroskedastisitas \\
X4 & 0,169 & Bebas Heteroskedastisitas \\
\hline
\end{tabular}

Sumber: Data diolah, 2018 
Berdasarkan Tabel 5 menunjukkan bahwa tidak ada satupun variabel bebas berpengaruh signifikan terhadap variabel terikat sehingga dapat disimpulkan model regresi penelitian ini bebas dari gejala heteroskedastisitas.

Analisis Statistik Deskriptif adalah pengujian statistik yang digunakan untuk menganalisis data dengan memberikan gambaran atau deskripsi terhadap suatu data mengenai nilai rata-rata (mean), standar deviasi, maksimum dan minimum. Statistik deskriptif merupakan statistik yang menggambarkan atau mendeskripsikan data menjadi sebuah informasi yang lebih mudah untuk dipahami. Tabel 6 menunjukkan hasil uji statistik deskriptif.

Tabel 6.

Hasil Analisis Statisik Deskriptif

\begin{tabular}{lccccc}
\hline \multicolumn{1}{c}{ Variabel } & $\mathrm{N}$ & Minimal & Maximum & Mean & $\begin{array}{c}\text { Standar } \\
\text { Deviasi }\end{array}$ \\
\hline Independensi $\left(\mathrm{X}_{1}\right)$ & 38 & 11 & 20 & 15,16 & 2,150 \\
Pengalaman Kerja $\left(\mathrm{X}_{2}\right)$ & 38 & 11 & 20 & 15,50 & 1,928 \\
Komitmen Organisasi $\left(\mathrm{X}_{3}\right)$ & 38 & 18 & 28 & 22,16 & 2,331 \\
Motivasi Auditor $\left(\mathrm{X}_{4}\right)$ & 38 & 10 & 18 & 14,82 & 2,154 \\
Kualitas Audit $(\mathrm{Y})$ & 38 & 15 & 24 & 20,32 & 2,107 \\
\hline
\end{tabular}

Sumber: Data diolah, 2018

Rata-rata (Mean) digunakan untuk mengukur nilai sentral dari suatu distribusi data dan standar deviasi digunakan untuk mengukur perbedaan nilai data yang diteliti dengan nilai rata-ratanya. Tabel 6 menunjukkan hasil statistik deskriptif sebagai berikut. 1) Diperoleh nilai terendah dari jumlah skor jawaban responden untuk variabel independensi sebesar 11 dan nilai tertinggi sebesar 20. Nilai rata-rata dari jumlah skor jawaban responden untuk variabel independensi adalah sebesar 15,16 hal ini berarti jika jumlah skor jawaban responden lebih besar dari 15,16 maka termasuk pada responden yang memiliki independensi yang tinggi. Jika jumlah skor jawaban responden lebih kecil dari 15,16 maka termasuk pada responden yang memiliki independensi yang rendah. Standar deviasi sebesar 
2,150 menunjukkan terjadi perbedaan nilai independensi yang diteliti dengan nilai rata-ratanya sebesar 2,$150 ; 2)$ Diperoleh nilai terendah dari jumlah skor jawaban responden untuk variabel pengalaman kerja sebesar 11 dan nilai tertinggi sebesar 20. Nilai rata-rata dari jumlah skor jawaban responden untuk variabel pengalaman kerja adalah sebesar 15,50 hal ini berarti jika jumlah skor jawaban responden lebih besar dari 15,50 maka termasuk pada responden yang memiliki pengalaman kerja yang tinggi. Jika jumlah skor jawaban responden lebih kecil dari 15,50 maka termasuk pada responden yang memiliki pengalaman kerja yang rendah. Standar deviasi sebesar 1,928 menunjukkan terjadi perbedaan nilai pengalaman kerja yang diteliti dengan nilai rata-ratanya sebesar 1,928; 3) Diperoleh nilai terendah dari jumlah skor jawaban responden untuk variabel komitmen organisasi sebesar 18 dan nilai tertinggi sebesar 28. Nilai rata-rata dari jumlah skor jawaban responden untuk variabel komitmen organisasi adalah sebesar 22,16 hal ini berarti jika jumlah skor jawaban responden lebih besar dari 22,16 maka termasuk pada responden yang memiliki komitmen organisasi yang tinggi. Jika jumlah skor jawaban responden lebih kecil dari 22,16 maka termasuk pada responden yang memiliki komitmen organisasi yang rendah. Standar deviasi sebesar 2,331 menunjukkan terjadi perbedaan nilai komitmen organisasi yang diteliti dengan nilai rata-ratanya sebesar 2,331 ; 4) Diperoleh nilai terendah dari jumlah skor jawaban responden untuk variabel motivasi auditor sebesar 10 dan nilai tertinggi sebesar 18. Nilai rata-rata dari jumlah skor jawaban responden untuk variabel motivasi auditor adalah sebesar 14,82 hal ini berarti jika jumlah skor jawaban responden lebih besar dari 14,82 maka termasuk pada responden yang memiliki 
motivasi auditor yang tinggi. Jika jumlah skor jawaban responden lebih kecil dari 14,82 maka termasuk pada responden yang memiliki motivasi auditor yang rendah. Standar deviasi sebesar 2,154 menunjukkan terjadi perbedaan nilai motivasi auditor yang diteliti dengan nilai rata-ratanya sebesar 2,154; 5) Diperoleh nilai terendah dari jumlah skor jawaban responden untuk variabel kualitas audit sebesar 15 dan nilai tertinggi sebesar 24. Nilai rata-rata dari jumlah skor jawaban responden untuk variabel kualitas audit adalah sebesar 20,32 hal ini berarti jika jumlah skor jawaban responden lebih besar dari 20,32 maka termasuk pada responden yang memiliki kualitas audit yang tinggi. Jika jumlah skor jawaban responden lebih kecil dari 20,32 maka termasuk pada responden yang memiliki kualitas audit yang rendah. Standar deviasi sebesar 2,107 menunjukkan terjadi perbedaan nilai kualitas audit yang diteliti dengan nilai rata-ratanya sebesar 2,107 .

Analisis regresi linier berganda digunakan untuk menguji pengaruh variabel independensi, pengalaman kerja, komitmen organisasi, motivasi auditor, dan kualitas audit. Hasil analisis regresi linier berganda dapat dilihat pada Tabel 7. 
ISSN: 2302-8556

E-Jurnal Akuntansi Universitas Udayana

Vol.27.3.Juni (2019): 2211-2238

Tabel 7.

Hasil Analisis Regresi Linier Berganda

\begin{tabular}{cccccc}
\hline Model & \multicolumn{2}{c}{ Unstandardized Coefficients } & $\begin{array}{c}\text { Standardized } \\
\text { Coefficients } \\
\text { Beta }\end{array}$ & $\mathrm{t}$ & Sig. \\
& $\mathrm{B}$ & Std. Error & & & \\
\hline (Constant) & $-2,393$ & 2,015 & & $-1,188$ & 0,243 \\
X1 & 0,394 & 0,081 & 0,402 & 4,892 & 0,000 \\
X2 & 0,387 & 0,094 & 0,354 & 4,130 & 0,000 \\
X3 & 0,360 & 0,075 & 0,398 & 4,800 & 0,000 \\
X4 & 0,187 & 0,073 & 0,191 & 2,568 & 0,015 \\
Adjusted R & 0,797 & & & & \\
F hitung & 37,399 & & & & \\
Sig. F & 0,000 & & & &
\end{tabular}

Berdasarkan Tabel 7 dapat disusun persamaan regresi sebagai berikut:

$$
Y=-2,393+0,394 X_{1}+0,387 X_{2}+0,360 X_{3}+0,187 X_{4}+e
$$

Berdasarkan persamaan di atas, dapat dijelaskan hal-hal sebagai berikut. 1)Nilai konstanta sebesar $-2,393$ memiliki tanda negative yang berarti bila nilai independensi $\left(\mathrm{X}_{1}\right)$, pengalaman kerja $\left(\mathrm{X}_{2}\right)$, komitmen organisasi $\left(\mathrm{X}_{3}\right)$, dan motivasi auditor $\left(\mathrm{X}_{4}\right)$ sama dengan nol, maka nilai kualitas audit akan cenderung menurun; 2) Nilai koefisien $\beta_{1}=X_{1} 0,394$ memiliki tanda positif. Hal ini bermakna bahwa independensi semakin meningkat, maka kualitas audit cenderung mengalami peningkatan dengan asumsi variabel bebas lainnya konstan; 3) Nilai koefisien $\beta_{2}=X_{2} 0,387$ memiliki tanda positif. Hal ini bermakna bahwa pengalaman kerja semakin meningkat, maka kualitas audit cenderung mengalami peningkatan dengan asumsi variabel bebas lainnya konstan; 4) Nilai koefisien $\beta_{3}=$ $\mathrm{X}_{3} 0,360$ memiliki tanda positif. Hal ini bermakna bahwa komitmen organisasi semakin meningkat, maka kualitas audit cenderung mengalami peningkatan dengan asumsi variabel bebas lainnya konstan; 5) Nilai koefisien $\beta_{4}=X_{4} 0,187$ memiliki tanda positif. Hal ini bermakna bahwa motivasi auditor semakin 
meningkat, maka kualitas audit cenderung mengalami peningkatan dengan asumsi variabel bebas lainnya konstan.

Koefisien determinasi digunakan untuk mengukur seberapa jauh kemampuan model dalam menerangkan variasi variabel dependen. Besarnya nilai koefisien determinasi $\left(\mathrm{R}^{2}\right)$ ditunjukkan dengan nilai $\mathrm{R}$ square. Hasil koefisien determinasi $\left(\mathrm{R}^{2}\right)$ dapat dilihat pada Tabel 8 .

Tabel 8.

Hasil Uji Koefisien Determinasi $\left(\mathbf{R}^{2}\right)$

\begin{tabular}{ccccc}
\hline Model & $\mathrm{R}$ & $\mathrm{R}$ Square & Adjusted R Square & $\begin{array}{c}\text { Std. Error of the } \\
\text { Estimate }\end{array}$ \\
\hline 1 & $0.905^{\mathrm{a}}$ & 0.819 & 0.797 & 0.948 \\
\hline
\end{tabular}

Sumber: Data diolah, 2018

Berdasarkan tabel 8 besarnya nilai Adjusted $\mathrm{R}$ square adalah sebesar 0,797 yang artinya sebesar 79,7 persen variasi kualitas audit dipengaruhi oleh independensi, pengalaman kerja, komitmen organisasi, dan motivasi auditor, sedangkan sisanya sebesar 20,3 persen dipengaruhi oleh faktor-faktor lain yang tidak dimasukkan ke dalam model penelitian.

Uji kelayakan model (uji F) dilakukan untuk mengetahui kelayakan model penelitian yang digunakan sebagai alat analisis untuk menguji pengaruh variabel independen terhadap variabel dependen. Apabila nilai signifikansi lebih kecil dari 0,05 maka variabel independen layak digunakan sebagai alat analisis. Hasil uji kelayakan model (uji F) dapat dilihat pada Tabel 9.

Tabel 9.

Hasil Uji Kelayakan Model (Uji F)

\begin{tabular}{cccccc}
\hline Model & Sum of Squares & Df & Mean Square & F & Sig. \\
\hline Regression & 134.533 & 4 & 33.633 & 37.399 & $0.000^{\mathrm{b}}$ \\
Residual & 29.677 & 33 & 0.899 & & \\
Total & 164.211 & 37 & & & \\
\hline
\end{tabular}

Sumber: Data diolah, 2018 
Berdasarkan hasil uji kelayakan model (uji F) pada tabel 9, menunjukkan bahwa hasil uji nilai signifikansi $\mathrm{F}$ adalah sebesar 0,000 yang lebih kecil dari 0,05 $(\mathrm{F}<\alpha)$ yang berarti variabel bebas yaitu independensi $\left(\mathrm{X}_{1}\right)$, pengalaman kerja $\left(\mathrm{X}_{2}\right)$, komitmen organisasi $\left(\mathrm{X}_{3}\right)$, dan motivasi auditor $\left(\mathrm{X}_{4}\right)$ berpengaruh signifikan secara serempak atau bersama-sama terhadap variabel terikat yaitu kualitas audit (Y), sehingga penelitian ini dapat dikatakan memenuhi uji kelayakan model atau model penelitian dinyatakan layak digunakan sebagai model regresi.

Hasil uji t, level of significant $(\alpha)$ yang digunakan adalah 0,05. Apabila tingkat signifikansi t hitung lebih kecil daripada 0,05 maka dapat dikatakan variabel bebas tersebut secara individual memengaruhi variabel terikat atau hipotesis diterima. Hasil uji t dapat dilihat pada Tabel 10.

Tabel 10.

Hasil Uji Hipotesis (Uji t)

\begin{tabular}{lccccc}
\hline Model & Unstandardized Coefficients & $\begin{array}{c}\text { Standardized } \\
\text { Coefficients } \\
\text { Beta }\end{array}$ & $\mathrm{t}$ & Sig. \\
& $\mathrm{B}$ & Std. Error & 0.015 & -1.188 & 0.243 \\
(Constant) & -2.393 & 2.015 & 4.892 & 0.000 \\
X1 & 0.394 & 0.081 & 0.402 & 0.000 \\
X2 & 0.387 & 0.094 & 0.354 & 4.130 & 0.000 \\
X3 & 0.360 & 0.075 & 0.398 & 4.800 & 0.015 \\
X4 & 0.187 & 0.073 & 0.191 & 2.568 & \\
a. Dependent Variable: Y & & & &
\end{tabular}

Sumber: Data diolah, 2018

Pada Tabel 10 dapat dilihat hasil dari pengujian parsial masing-masing variabel bebas pada variabel terikat yang dijabarkan sebagai berikut. 1) Variabel independensi (X1) memiliki tingkat signifikansi t sebesar 0,000 lebih kecil dari 0,05. Hal ini berarti hipotesis pertama diterima yaitu independensi berpengaruh positif pada kualitas audit; 2) Variabel pengalaman kerja (X2) memiliki tingkat signifikansi t sebesar 0,000 lebih kecil dari 0,05. Hal ini berarti hipotesis kedua diterima yaitu pengalaman kerja berpengaruh positif pada kualitas audit; 
3)Variabel komitmen organisasi (X3) memiliki tingkat signifikansi t sebesar 0,000 lebih kecil dari 0,05 . Hal ini berarti berarti hipotesis ketiga diterima yaitu komitmen organisasi berpengaruh positif pada kualitas audit; 4)Variabel motivasi auditor (X4) memiliki tingkat signifikansi t sebesar 0,015 lebih kecil dari 0,05. Hal ini berarti berarti hipotesis keempat diterima yaitu motivasi auditor berpengaruh positif pada kualitas audit.

Hasil uji parsial menunjukkan adanya pengaruh positif independensi pada kualitas audit. Nilai t hitung variabel independensi adalah sebesar 4,892 yang artinya berpengaruh positif dengan nilai signifikansi sebesar $0,000<0,05$ yang artinya signifikan. Hasil ini menerima hipotesis $\mathrm{H}_{1}$ yang menyatakan independensi berpengaruh positif pada kualitas audit. Hasil penelitian ini konsisten dengan penelitian yang dilakukan oleh (Septriani, 2012) yang menyatakan bahwa independensi berpengaruh signifikan positif terhadap kualitas audit. Dalam penelitian yang dilakukan oleh (Badjuri, 2011) diperoleh hasil bahwa independensi berpengaruh positif terhadap kualitas audit. Sama halnya dengan penelitian yag dilakukan oleh (Bawono and Singgih, 2010) bahwa terdapat pengaruh positif independensi auditor terhadap kualitas audit.Berdasarkan penemuan tersebut, maka dapat digambarkan bahwa independensi memiliki peran penting bagi auditor Inspektorat Provinsi Bali dalam menghasilkan kualitas audit yang baik. Semakin tidak berpihaknya (independen) seorang auditor pemerintah dalam melakukan audit, maka hasil pemeriksaannya akan sesuai dengan fakta-fakta yang ada sehingga kualitas audit akan semakin baik. 
Hasil uji parsial menunjukkan adanya pengaruh positif pengalaman kerja pada kualitas audit. Nilai t hitung variabel pengalaman kerja adalah sebesar 4,130 yang artinya berpengaruh positif dengan nilai signifikansi sebesar $0,000<0,05$ yang artinya signifikan. Hasil ini menerima hipotesis $\mathrm{H}_{2}$ yang menyatakan pengalaman kerja berpengaruh positif pada kualitas audit. Hasil penelitian ini konsisten dengan penelitian yang dilakukan oleh (Agusti and Pertiwi 2013) yang menyatakan bahwa pengalaman kerja berpengaruh positif terhadap kualitas audit. Pada penelitian yang dilakukan oleh (Hanjani Andreani, 2014) dan (Panggih Hastama 2015) membuktikan bahwa pengalaman kerja berpengaruh positif terhadap kualitas audit. Berdasarkan penemuan tersebut, maka dapat digambarkan bahwa pengalaman merupakan hal yang sangat penting bagi sebuah profesi yang membutuhkan profesinalisme yang sangat tinggi seperti auditor, karena pengalaman akan mempengaruhi kualitas audit seorang auditor.

Hasil uji parsial menunjukkan adanya pengaruh positif komitmen organisasi pada kualitas audit. Nilai t hitung variabel komitmen organisasi adalah sebesar 4,800 yang artinya berpengaruh positif dengan nilai signifikansi sebesar $0,000<0,05$ yang artinya signifikan. Hasil ini menerima hipotesis $\mathrm{H}_{3}$ yang menyatakan komitmen organisasi berpengaruh positif pada kualitas audit. Hasil penelitian ini konsisten dengan penelitian yang dilakukan oleh (Putri, 2015) yang menyatakan bahwa komitmen organisasi berpengaruh positif pada kualitas audit. Begitu pula dengan penelitian yang dilakukan oleh (Suryantini, 2012) yang menyatakan bahwa komitmen organisasi berpengaruh positif terhadap kualitas audit. Berdasarkan penemuan tersebut, maka dapat digambarkan bahwa auditor 
yang memiliki komitmen terhadap organisasinya secara profesional akan mempertahankan kode etik dan standar pemeriksaan yang telah ditetapkan. Auditor yang memiliki komitmen organisasi yang tinggi akan bersikap loyal pada organisasi untuk dapat menghasilkan kualitas audit yang baik.

Hasil uji parsial menunjukkan adanya pengaruh positif motivasi auditor pada kualitas audit. Nilai t hitung variabel motivasi auditor adalah sebesar 2,568 yang artinya berpengaruh positif dengan nilai signifikansi sebesar 0,015<0,05 yang artinya signifikan. Hasil ini menerima hipotesis $\mathrm{H}_{3}$ yang menyatakan motivasi auditor berpengaruh positif pada kualitas audit. Hasil penelitian ini konsisten dengan penelitian yang dilakukan oleh (Effendy, 2010) yang menyatakan bahwa motivasi berpengaruh positif terhadap kualitas audit. Pada penelitian yang dilakukan oleh (Hanjani Andreani, 2014) dan (Idawati, 2015) juga ditemukan bahwa bahwa motivasi berpengaruh positif terhadap kualitas audit. Berdasarkan penelitian diatas dapat digambarkan bahwa motivasi merupakan salah satu faktor yang cukup penting pada kualitas hasil dari pekerjaan yang dihasilkan seseorang dalam menjalankan pekerjaannya, terutama untuk seorang auditor yang sering kali menjadikan motivasinya sebagai dorongan untuk menghasilkan laporan audit yang berkualitas.

\section{SIMPULAN}

Independensi berpengaruh positif pada kualitas audit. Semakin independen seorang auditor, maka tidak akan mudah terpengaruh dalam merumuskan dan 
menyatakan pendapatnya sehingga kualitas audit yang dihasilkan akan semakin baik.

Pengalaman kerja berpengaruh positif pada kualitas audit. Pengalaman kerja yang telah dimiliki selama menjadi auditor akan mendukung keterampilan dan kecepatan dalam menyelesaikan tugas yang diberikan sehingga tingkat kesalahan akan semakin berkurang dan kualitas audit akan semakin baik.

Komitmen organisasi berpengaruh positif pada kualitas audit. Seorang auditor yang memiliki komitmen terhadap organisasinya, akan menunjukkan loyalitas dirinya terhadap organisasi tempatnya bekerja untuk menghasilkan kualitas audit yang baik; 4)Motivasi Auditor berpengaruh positif pada kualitas audit. Motivasi merupakan salah satu faktor yang cukup penting pada kualitas hasil dari pekerjaan yang dihasilkan seseorang dalam menjalankan pekerjaannya, terutama untuk seorang auditor yang sering kali menjadikan motivasinya sebagai dorongan untuk menghasilkan laporan audit yang berkualitas.

Pimpinan pada Inspektorat Provinsi Bali diharapkan dapat memberikan telaah pada auditor untuk menilai prosedur audit yang digunakan agar dapat menghasilkan kualitas audit yang baik. Pimpinan pada Inspektorat Provinsi Bali diharapkan dapat memberikan review atas hasil pekerjaan yang telah dilaksanakan oleh para auditor. Review ini sangat bermanfaat dalam menambah pengalaman dan wawasan auditor.

Auditor pada Inspektorat Provinsi Bali diharapkan memiliki komitmen terhadap organisasinya, sehingga akan bersikap loyal untuk terus meningkatkan kinerjanya sebagai seorang auditor agar dapat menciptakan kualitas audit yang 
Ida Bagus Putu Angga Mardika dan I Wayan Suartana. Pengaruh ...

baik. Loyalitas terhadap organisasi dapat ditingkatkan dengen pemberian pelatihan mengenai keorganisasian yang dapat diberikan oleh pemerintah daerah.

Sebaiknya hasil audit yang telah dilaksanakan oleh para auditor dipergunakan dengan baik oleh penentu kebijakan sehingga akan memberi pengaruh yang cukup besar bagi peningkatan kualitas pelayanan publik.

\section{REFERENSI}

Badjuri, Acmat. 2011. "Faktor-Faktor Yang Berpengaruh Terhadap Kualitas Audit Auditor Independen Pada Kantor Akkuntan Publik (KAP) Di Jawa Tengah.” Dinamika Keuangan dan Perbankan 3 (2).

Basrowi, Suwandi. 2008. Prosedur Penelitian Tindakan Kelas. Ghalia Indonesia : Anggota IKAPI.

Bawono, I.R, and Elisha Muliani Singgih. 2010. "Faktor-Faktor Dalam Diri Auditor Dan Kualitas Audit: Studi Pada KAP ‘Big Four’ Di Indonesia.”

Christiawan, Yulius Jogi. 2002. "Kompetensi Dan Independensi Akuntan Publik: Refleksi Hasil Penelitian Empiris." Journal Directory. Kumpulan Jurnal Akuntansi dan Keuangan Unika Petra 4(2).

Effendy, M. Taufiq. 2010. "Pengaruh Kompetensi, Independensi, Dan Motivasi Terhadap Kualitas Audit Aparat Inspektorat Dalam Pengawasan Keuangan Daerah.” Universitas Diponegoro Semarang.

Fatimah, Annisa. 2012. "Karakteristik Personal Auditor Sebagai Anteseden Perilaku Disfungsional Auditor Dan Pengaruhnya Terhadap Kualitas Hasil Audit." Jurnal Manajemen dan Akuntansi 1 (1): 1-12.

Hanjani Andreani, Rahardja. 2014. "Pengaruh Etika Auditor, Pengalaman Auditor, Fee Audit, Dan Motivasi Auditor Terhadap Kualitas Audit (Studi Empiris Pada Kantor KAP Di Semarang).” 3 (2) ISSN: 1-9.

Idawati, Wiwi. 2015. "Effect of Audit Rotation, Audit Fee, And Auditor Competence to Motivation Auditor and Implications on Audit Quality (Case Study Of Registered Public Accountant Firms at Bank Indonesia)." Journal of Economic and Sustainable Development 6 (6): 78-109. 
Ikatan Akuntan Indonesia. 2011. Standar Profesional Akuntan Publik. Jakarta: Salemba Empat.

Jensen, and Meckling. 1976. "The Theory of The Firm: Manajerial Behaviour, Agency Cost, and Ownership Structure." Journal of Financial and Economics 3: 3025-3360.

Mardiasmo. 2005. Akuntansi Sektor Publik. Edisi 2. Yogyakarta: Penerbit Andi.

Panggih Hastama, Lutiari. 2015. "Pengaruh Independensi, Pengalaman, Due Profesional Care, Dan Akuntabilitas Terhadap Kualitas Audit (Studi Empiris Pada Kantor Akuntan Publik Daerah Istimewa Yogyakarta)." Universitas Sanata Dharma Yogyakarta.

Putri, Yola Mentari. 2015. "Pengaruh Komitmen Organisasi, Profesionalisme Dan Perilaku Etis Terhadap Kinerja Auditor Di Kantor Akuntan Publik Wilayah Yogyakarta.” Universitas Negeri Yogyakarta.

Sari, NPP Fortuna, and I. W Ramantha. 2015. "Pengaruh Sikap Skeptisme, Pengalaman Audit, Kompetensi, Dan Independensi Auditor Pada Kualitas Audit." E-Jurnal Akuntansi Universitas Udayana 11(2): 470-82.

Septriani, Rossi. 2012. "Pengaruh Independensi Dan Kompetensi Auditor Terhadap Kualitas Audit.” Jurnal Akuntansi dan Manajemen 7(2) Desem.

Sugianto, Chyntia Anawati. 2012. "Pengaruh Independensi, Pengalaman, Due Professional Care Dan Akuntabilitas Terhadap Kualitas Audit.” Universitas Katolik Widya Mandala Surabaya.

Sugiyono. 2014. Metode Penelitian Bisnis. Bandung: Alfabeta.

Sukriah, Ika, and Dkk. 2009. "Pengaruh Pengalaman Kerja, Independensi, Objektivitas, Integritas, Dan Kompetensi Terhadap Kualitas Hasil Pemeriksaan.” Simposium Nasional Akuntansi XII Palembang.

Suryantini, Ni Putu Ayu. 2012. "Pengaruh Kompetensi Auditor, Komitmen Organisasi, Dan Besaran Fee Audit Terhadap Kualitas Audit Pada Kantor Akuntan Publik Di Bali.” E-Jurnal Akuntansi Universitas Udayana.

Suyana, Utama. 2012. Buku Ajar Aplikasi Analisis Kuantitatif. Edisi Keen. Denpasar.

Yushita, Amanita Novi, and Rahmawati Hanung Triatmoko. 2013. "Pengaruh Mekanisme Corporate Governance, Kualitas Auditor, Dan Likuiditas Terhadap Kualitas Laba.” Jurnal Economia 9(2): 141-55. 
Ida Bagus Putu Angga Mardika dan I Wayan Suartana. Pengaruh ...

Zeyn, Elvira. 2011. "Pengaruh Good Governance Dan Standar Akuntansi Pemerintahan Terhadap Akuntabilitas Keuangan Dengan Komitmen Organisasi Sebagai Pemoderasi." E-journal Universitas Muhammadiyah Malang 7(22): 124-36. 